\title{
Front Matter: Volume 7441A
}

, "Front Matter: Volume 7441A," Proc. SPIE 7441, Instruments and Methods for Astrobiology and Planetary Missions XII, 744119 (30 September 2009); doi: $10.1117 / 12.837065$

EDIE Event: SPIE Optical Engineering + Applications, 2009, San Diego, California, United States 


\section{PROCEEDINGS OF SPIE}

\section{Instruments and Methods for Astrobiology and Planetary Missions XII}

Richard B. Hoover

Gilbert V. Levin

Alexei Yu. Rozanov

Kurt D. Retherford

Editors

4-6 August 2009

San Diego, California, United States

Sponsored and Published by

SPIE

Volume 7441

Proceedings of SPIE, 0277-786X, v. 7441 
The papers included in this volume were part of the technical conference cited on the cover and title page. Papers were selected and subject to review by the editors and conference program committee. Some conference presentations may not be available for publication. The papers published in these proceedings reflect the work and thoughts of the authors and are published herein as submitted. The publisher is not responsible for the validity of the information or for any outcomes resulting from reliance thereon.

Please use the following format to cite material from this book:

Author(s), "Title of Paper," in Instruments and Methods for Astrobiology and Planetary Missions XII, edited by Richard B. Hoover, Gilbert V. Levin, Alexei Yu. Rozanov, Kurt D. Retherford, Proceedings of SPIE Vol. 7441 (SPIE, Bellingham, WA, 2009) Article CID Number.

ISSN 0277-786X

ISBN 9780819477316

Published by

SPIE

P.O. Box 10, Bellingham, Washington 98227-0010 USA

Telephone +1 3606763290 (Pacific Time) · Fax +1 3606471445

SPIE.org

Copyright (C) 2009, Society of Photo-Optical Instrumentation Engineers

Copying of material in this book for internal or personal use, or for the internal or personal use of specific clients, beyond the fair use provisions granted by the U.S. Copyright Law is authorized by SPIE subject to payment of copying fees. The Transactional Reporting Service base fee for this volume is $\$ 18.00$ per article (or portion thereof), which should be paid directly to the Copyright Clearance Center (CCC), 222 Rosewood Drive, Danvers, MA 01923. Payment may also be made electronically through CCC Online at copyright.com. Other copying for republication, resale, advertising or promotion, or any form of systematic or multiple reproduction of any material in this book is prohibited except with permission in writing from the publisher. The CCC fee code is 0277-786X/09/ $\$ 18.00$.

Printed in the United States of America.

Publication of record for individual papers is online in the SPIE Digital Library.

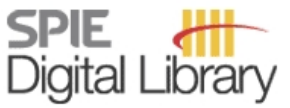

SPIEDigitalLibrary.org

Paper Numbering: Proceedings of SPIE follow an e-First publication model, with papers published first online and then in print and on CD-ROM. Papers are published as they are submitted and meet publication criteria. A unique, consistent, permanent citation identifier (CID) number is assigned to each article at the time of the first publication. Utilization of CIDs allows articles to be fully citable as soon they are published online, and connects the same identifier to all online, print, and electronic versions of the publication. SPIE uses a six-digit CID article numbering system in which:

- The first four digits correspond to the SPIE volume number.

- The last two digits indicate publication order within the volume using a Base 36 numbering system employing both numerals and letters. These two-number sets start with 00, 01, 02, 03, 04, $05,06,07,08,09,0 A, 0 B \ldots 0 Z$, followed by 10-1Z, 20-2Z, etc.

The CID number appears on each page of the manuscript. The complete citation is used on the first page, and an abbreviated version on subsequent pages. Numbers in the index correspond to the last two digits of the six-digit CID number. 


\section{Contents}

ix Conference Committee

xiii Introduction for Part 1: Instrumentation, Methods, and Missions for Astrobiology XII

\section{PART 1 Instruments, Methods, and Missions for Astrobiology XII}

\section{SESSION 1 MICROFOSSILS AND BIOMARKERS IN METEORITES AND ANCIENT TERRESTRIAL ROCKS I}

744102 Life on Mars: new evidence from Martian meteorites (Invited Paper) [7441B-01]

D. S. McKay, K. L. Thomas-Keprta, S. J. Clemett, E. K. Gibson, Jr., L. Spencer, S. J. Wentworth, NASA Johnson Space Ctr. (United States)

744103 Microfossils in carbonaceous meteorites [7441B-02]

R. B. Hoover, NASA Marshall Space Flight Ctr. (United States)

744104 Volcanic glasses as habitat for microfossils: evidence from the early Paleoproterozoic pillow lavas of Karelia and their modern analogues in the Mid-Atlantic Ridge [7441B-03] M. M. Astafieva, A. Yu. Rozanov, Paleontological Institute (Russian Federation); E. V. Sharkov, A. V. Chistyakov, M. M. Bogina, Institute of Geology of Ore Deposits, Petrography, Mineralogy, and Geochemistry (Russian Federation); R. B. Hoover, NASA Marshall Space Flight Ctr. (United States)

\section{SESSION 2 MICROFOSSILS AND BIOMARKERS IN METEORITES AND ANCIENT TERRESTRIAL ROCKS II}

744105 Partial racemization of amino acids in meteorites: implications for their possible modes of origin (Invited Paper) [7441B-04]

M. H. Engel, The Univ. of Oklahoma (United States)

744106 On the search for the amino acids on the lunar surface as it relates to other extraterrestrial bodies [7441B-05]

V. M. Kolb, Univ. of Wisconsin-Parkside (United States); R. B. Hoover, NASA Marshall Space Flight Ctr. (United States); S. A. Macko, Univ. of Virginia (United States)

744107 Fossil microorganisms and formation of Early Precambrian weathering crusts (Invited Paper) [7441B-06]

M. M. Astafieva, A. Yu. Rozanov, Paleontological Institute (Russian Federation); A. B. Vrevsky, N. A. Alfimova, V. A. Matrenichev, Institute of Precambrian Geology and Geochronology (Russian Federation); R. B. Hoover, NASA Marshall Space Flight Ctr. (United States) 
744108 A spectroscopic polarimeter for detecting chiral signatures in astrobiological samples (Invited Paper) [7441B-07]

B. Wang, Hinds Instruments, Inc. (United States); W. B. Sparks, Space Telescope Science Institute (United States); T. A. Germer, National Institute of Standards and Technology (United States); A. Leadbetter, Hinds Instruments, Inc. (United States)

744109 Laser induced fluorescence emission (L.I.F.E.): in situ and remote detection of life in Antarctic and Alaskan ice (Invited Paper) [7441B-08]

M. C. Storrie-Lombardi, Kinohi Institute (United States); B. Sattler, Univ. of Innsbruck (Austria)

$7441 \mathrm{OA}$ Integrated ray tracing simulation of spectral bio-signatures from full 3D earth model (Invited Paper) [7441B-09]

D. Ryu, S. Seong, Yonsei Univ. (Korea, Republic of); J.-M. Lee, Univ. of Oxford (United Kingdom); J. Hong, I\&A Technology (Korea, Republic of); S. Jeong, Y. Jeong, S.-W. Kim, Yonsei Univ. (Korea, Republic of)

7441 OB A micro fluorescent activated cell sorter for astrobiology applications [7441B-10] D. W. Platt, Micro Aerospace Solutions, Inc. (United States); R. B. Hoover, NASA National Space Science and Technology Ctr. (United States)

\section{SESSION 4 MARS, VENUS, AND ASTROBIOLOGY I}

7441 OC The discovery of liquid water on Mars and its implications for astrobiology (Invited Paper) [7441B-11]

N. O. Rennó, M. Mehta, B. P. Block, S. Braswell, Univ. of Michigan (United States)

7441 OD Methane and life on Mars (Invited Paper) [7441B-12]

G. V. Levin, Arizona State Univ. (United States); P. A. Straat, NIH-retired (United States)

$7441 \mathrm{OE}$ Oxidation of organic materials with perchlorates: relevance to the chemistry on the Martian surface (Invited Paper) [7441B-13]

V. M. Kolb, Univ. of Wisconsin-Parkside (United States)

\section{SESSION 5 MARS, VENUS, AND ASTROBIOLOGY II}

7441 OG Multi-fractal property of perchlorate reductase gene sequences and DNA photonics application to UV fluorescence detection on Mars-like surfaces (Invited Paper) [7441B-14] G. Tremberger, Jr., E. Cheung, N. Gadura, T. Holden, R. Subramaniam, R. Sullivan, P. Schneider, A. Flamholz, D. H. Lieberman, T. D. Cheung, Queensborough Community College, CUNY (United States)

$7441 \mathrm{OH}$ Can Venus shed microorganisms? [7441B-15]

G. Konesky, K-Plasma Ltd. (United States) 
7441 Ol Raman imaging for high throughput biomarker field detections [7441B-34]

Z. Tanaka, Univ. of California, Santa Cruz (United States) and NASA Ames Research Ctr. (United States); T. Beer, Martin-Luther-Univ. Halle-Wittenberg (Germany); C. P. McKay, R. Bonaccorsi, NASA Ames Research Ctr. (United States); C. GU, B. Chen, Univ. of California, Santa Cruz (United States) and NASA Ames Research Ctr. (United States)

\section{SESSION $6 \quad$ MICROBIAL EXTREMOPHILES I}

7441 0J Diversity of bacterial communities in the lakes of Schirmacher Oasis, Antarctica (Invited Paper) [7441B-17]

N. Mojib, J. Huang, The Univ. of Alabama at Birmingham (United States); R. B. Hoover, NASA National Space Science and Technology Ctr., (United States); E. V. Pikuta, The Univ. of Alabama at Huntsville (United States); M. Storrie-Lombardi, Kinohi Institute (United States); B. Sattler, Univ. of Innsbruck (Austria); D. Andersen, SETI Institute (United States); A. K. Bej, The Univ. of Alabama at Birmingham (United States)

7441 OK Anaerobic psychrophiles from Lake Zub and Lake Untersee, Antarctica [7441B-18] A. Townsend, E. V. Pikuta, M. Guisler, S. Stahl, R. B. Hoover, National Space Science and Technology Ctr. (United States) and Univ. of Alabama in Huntsville (United States)

7441 OL Psychrotolerant anaerobes from Lake Podprudnoye, Antarctica and penguin Spheniscus demersus colony, South Africa [7441B-19]

M. Guisler, E. V. Pikuta, A. Townsend, R. B. Hoover, NASA National Space Science and Technology Ctr. (United States) and Univ. of Alabama in Huntsville (United States)

7441 OM Cryoprotection from bacterial teichoic acid (Invited Paper) [7441B-20]

C. V. Rice, W. Harrison, K. Kirkpatrick, Univ. of Oklahoma (United States); E. D. Brown, McMaster Univ. (Canada)

$74410 \mathrm{~N} \quad$ An optical spectroscopic study correlating the yellow rain and cultured red rain microbes (Invited Paper) [7441B-21]

A. S. Kumar, Mahatma Gandhi Univ. (India); G. Lovis, Cochin Univ. of Science \& Technology (India)

\section{SESSION 7 MICROBIAL EXTREMOPHILES II}

7441 OP Life in ice: implications to astrobiology [7441B-23]

R. B. Hoover, E. V. Pikuta, NASA Mashall Space Flight Ctr. (United States)

7441 OR Nucleotide fluctuation of radiation-resistant Halobacterium sp. NRC-1 single-stranded DNA-binding protein (RPA) genes (Invited Paper) [7441B-25]

T. Holden, G. Tremberger, Jr., E. Cheung, R. Subramaniam, N. Gadura, P. Schneider, R. Sullivan, A. Flamholz, D. Lieberman, T. D. Cheung, Queensborough Community College, CUNY (United States) 
7441 OS Origin of petroleum within our solar system, a review: emphasis on the future prospects of major oil and gas discovery within Mars and moons of various planets (Invited Paper) [7441B-26]

P. K. Mukhopadhyay, Global Geoenergy Research Ltd. (Canada); D. J. Mossman, J. M. Ehrman, Mt. Allison Univ. (Canada)

7441 OT Panspermia and horizontal gene transfer [7441B-27]

B. Klyce, Astrobiology Research Trust (United States)

$7441 \mathrm{OU}$ On the applicability of the identity problem to astrobiology [7441B-28]

V. M. Kolb, Univ. of Wisconsin-Parkside (United States)

7441 OV Astrobiology and green chemistry: a new pedagogical connection [7441B-29]

V. M. Kolb, Univ. of Wisconsin-Parkside (United States)

7441 OW The Drake Equation revisited [7441B-30]

G. Konesky, K-Plasma Ltd. (United States)

\section{PART 2 X-Ray, UV, Visible, and IR Instrumentation for Planetary Missions}

\section{SESSION $1 \quad$ X-RAY, UV, VISIBLE, AND IR INSTRUMENTATION FOR PLANETARY MISSIONS}

$74410 X \quad$ Planetary science experiments flying as hosted payloads on commercial satellites [7441A-35]

E. F. Young, C. B. Olkin, Southwest Research Institute (United States); P. M. Kalmanson, Orbital Sciences Corp. (United States); R. Mellon, Equinox Interscience Inc. (United States); M. Young, Univ. of Colorado (United States)

7441 OY In-flight performance of the Long Range Reconnaissance Imager (LORRI) on the New Horizons Mission [7441A-36]

M. W. Noble, S. J. Conard, H. A. Weaver, J. R. Hayes, A. F. Cheng, Johns Hopkins Univ. (United States)

$74410 Z$ In-flight performance of MESSENGER's Mercury Dual Imaging System [7441A-37] S. E. Hawkins III, S. L. Murchie, The Johns Hopkins Univ. (United States); K. J. Becker, U.S. Geological Survey (United States); C. M. Selby, F. S. Turner, M. W. Noble, N. L. Chabot, T. H. Choo, E. H. Darlington, The Johns Hopkins Univ. (United States); B. W. Denevi, Arizona State Univ. (United States); D. L. Domingue, C. M. Ernst, The Johns Hopkins Univ. (United States); G. M. Holsclaw, Univ. of Colorado (United States); N. R. Laslo, The Johns Hopkins Univ. (United States); W. E. McClintock, Univ. of Colorado (United States); L. M. Prockter, The Johns Hopkins Univ. (United States); M. S. Robinson, Arizona State Univ. (United States);

S. C. Solomon, Carnegie Institution of Washington (United States); R. E. Sterner II, The Johns Hopkins Univ. (United States)

744110 Radiometric performance results of the Lunar Reconnaissance Orbiter's Lyman Alpha Mapping Project (LRO/LAMP) UV imaging spectrograph [7441 A-38]

M. W. Davis, D. C. Slater, G. R. Gladstone, S. A. Stern, T. K. Greathouse, K. D. Retherford, M. H. Versteeg, R. K. Black, Southwest Research Institute (United States) 
744111 SwRI's Alice line of ultraviolet spectrographs [7441A-39]

K. D. Retherford, S. A. Stern, D. C. Slater, G. R. Gladstone, M. W. Davis, J. W. Parker, M. H. Versteeg, A. J. Steffl, T. K. Greathouse, N. J. Cunningham, Southwest Research Institute (United States)

744112 CRISM scan system [7441A-40]

K. Strohbehn, T. Choo, J. Hayes, G. Heyler, J. Lees, D. Lohr, The Johns Hopkins Univ. (United States); G. Seagrave, Gordonicus LLC (United States)

744114 Moon4You: a combined Raman/LIBS instrument for lunar exploration [7441 A-42]

E. C. Laan, B. Ahlers, TNO Science and Industry (Netherlands); W. van Westrenen, Vrije Univ. Amsterdam (Netherlands); J. Heiligers, TNO Science and Industry (Netherlands); A. Wielders, Space Horizon (Netherlands)

744115 The Mercury Imaging X-ray Spectrometer: instrument overview [7441A-43]

A. Martindale, J. F. Pearson, C. Whitford, G. W. Fraser, Univ. of Leicester (United Kingdom); D. A. Rothery, The Open Univ. (United Kingdom); D. Talboys, Univ. of Leicester (United Kingdom); J. D. Carpenter, ESA-ESTEC (Netherlands); T. Stevenson, E. Bunce, Univ. of Leicester (United Kingdom); R. Fairbend, J. Seguy, Photonis France S.A.S. (France); E. Sclater, I. Delgado, A. Dixon, Magna Parva Ltd. (United Kingdom); J. Treis, Max-Planck-Institut für extraterrestrische Physik (Germany); J. M. Mas-Hesse, Ctr. de Astrobiologia, CSIC-INTA (Spain); J. L. San Juan, LIDAX (Spain); K. Muinonen, Univ. of Helsinki (Finland); C. Sawyers, Univ. of Leicester (United Kingdom); C. Bulloch, Magna Parva Ltd. (United Kingdom); E. Schyns, Photonis France S.A.S. (France)

744116 DEPFET-based instrumentation for the MIXS focal plane on BepiColombo [7441A-44] J. Treis, MPI Halbleiterlabor (Germany) and Max-Planck-Institut für Sonnensystemforschung (Germany); L. Andricek, MPI Halbleiterlabor (Germany) and Max-Planck-Institut für Physik (Germany); F. Aschaver, S. Herrmann, MPI Halbleiterlabor (Germany) and Max-Planck-Institut für extraterrestrische Physik (Germany); K. Heinzinger, MPI Halbleiterlabor (Germany) and PNSensor GmbH (Germany); M. Hilchenbach, Max-Planck-Institut für Sonnensystemforschung (Germany); T. Lauf, MPI Halbleiterlabor (Germany) and Max-Planck-Institut für extraterrestrische Physik (Germany); P. Lechner, G. Lutz, P. Majewski, MPI Halbleiterlabor (Germany) and PNSensor GmbH (Germany); M. Porro, MPI Halbleiterlabor (Germany) and Max-Planck-Institut für extraterrestrische Physik (Germany); R. H. Richter, MPI Halbleiterlabor (Germany) and Max-Planck-Institut für Physik (Germany); G. Schaller, MPI Halbleiterlabor (Germany) and Max-Planck-Institut für extraterrestrische Physik (Germany); M. Schnecke, MPI Halbleiterlabor (Germany) and Max-Planck-Institut für Physik (Germany); F. Schopper, MPI Halbleiterlabor (Germany) and Max-Planck-Institut für extraterrestrische Physik (Germany); H. Soltau, MPI Halbleiterlabor (Germany) and PNSensor GmbH (Germany); A. Stefanescu, MPI Halbleiterlabor (Germany) and Johannes Gutenberg Univ. Mainz (Germany); L. Strüder, G. de Vita, MPI Halbleiterlabor (Germany) and Max-Planck-Institut für extraterrestrische Physik (Germany) 


\section{POSTER SESSION}

744117 The Mercury Imaging X-ray Spectrometer: optics design and characterisation [7441A-45] A. Martindale, J. F. Pearson, G. W. Fraser, Univ. of Leicester (United Kingdom); J. D. Carpenter, ESA-ESTEC (Netherlands); R. Willingale, T. Stevenson, C. Whitford, Univ. of Leicester (United Kingdom); F. Giannini, ESA-ESTEC (Netherlands); R. Fairbend, J. Seguy, Photonis France S.A.S. (France); E. Sclater, I. Delgado, Magna Parva Ltd. (United Kingdom); M. Kaipiainen, S. Nenonen, T. Pilvi, Oxford Instruments Analytical Oy (Finland); E. Schyns, Photonis France S.A.S. (France); C. Bulloch, Magna Parva Ltd. (United Kingdom); C. Sawyers, Univ. of Leicester (United Kingdom); K. Muinonen, Univ. of Helsinki (Finland)

744118 Development of a silicon drift detector array: an x-ray fluorescence spectrometer for remote surface mapping [7441A-46]

J. A. Gaskin, NASA Marshall Space Flight Ctr. (United States); G. A. Carini, W. Chen, G. De Geronimo, Brookhaven National Lab. (United States); R. F. Elsner, NASA Marshall Space Flight Ctr. (United States); J. W. Keister, Brookhaven National Lab. (United States); G. Kramer, The Bear Fight Ctr. (United States); Z. Li, Brookhaven National Lab. (United States); B. D. Ramsey, NASA Marshall Space Flight Ctr. (United States); P. Rehak, D. P. Siddons, Brookhaven National Lab. (United States)

Author Index 


\title{
Conference Committees
}

\author{
Program Track Chair
}

Oswald H. Siegmund, University of California, Berkeley (United States)

\section{Part 1 Instruments, Methods, and Missions for Astrobiology XII}

\section{Conference Chairs}

Richard B. Hoover, NASA Marshall Space Flight Center (United States) and National Space Science and Technology Center (United States) Gilbert V. Levin, Arizona State University (United States)

Alexei Yu. Rozanov, Paleontological Institute (Russian Federation)

\section{Program Committee}

Oleg N. Abramenko, Lomonosov Moscow State University (Russian Federation)

Sabit S. Abyzov, Institute of Microbiology (Russian Federation)

Marina M. Astafieva, Paleontological Institute (Russian Federation)

Stanley M. Awramik, University of California, Santa Barbara (United States)

Asim Bej, The University of Alabama at Birmingham (United States)

Adrian J. Brown, SETI Institute (United States)

Mark J. Burchell, University of Kent (United Kingdom)

Nathalie A. Cabrol, NASA Ames Research Center (United States)

Julian Chela-Flores, The Abdus Salam International Center for Theoretical Physics (Italy)

Bin Chen, NASA Ames Research Center (United States)

Michael H. Engel, University of Oklahoma (United States)

Valery Galchenko, Institute of Microbiology (Russian Federation)

Victor A. Gallardo, Universidad de Concepción (Chile)

Everett J. Gibson, NASA Johnson Space Center (United States)

Todd M. Holden, Queensborough Community College, City University of New York (United States)

Vera M. Kolb, University of Wisconsin-Parkside (United States)

A. Santhosh Kumar, Mahatma Gandhi University (India)

Laurence Lemelle, École Normale Supérieure de Lyon (France)

Jere H. Lipps, University of California, Berkeley (United States)

Godfrey Louis, Cochin University of Science and Technology (India)

David S. McKay, NASA Johnson Space Center (United States)

P. K. Mukhopadhvay, Global Geoenergy Research Ltd. (Canada)

Randall S. Perry, Imperial College London (United Kingdom) 
Elena V. Pikuta, National Space Science and Technology Center

(United States)

Joseph Seckbach, The Hebrew University of Jerusalem (Israel)

Michael C. Storrie-Lombardi, Kinohi Institute (United States)

Henry Sun, Desert Research Institute (United States)

George Tremberger, Jr., Queensborough Community College, City

University of New York (United States)

Esta Van Heerden, University of the Free State (South Africa)

Nalin Chandra Wickramasinghe, Cardiff University (United Kingdom)

Session Chairs

1 Microfossils and Biomarkers in Meteorites and Ancient Terrestrial Rocks I

Michael H. Engel, University of Oklahoma (United States)

Marina M. Astafieva, Paleontological Institute (Russian Federation)

2 Microfossils and Biomarkers in Meteorites and Ancient Terrestrial

Rocks II

Vera M. Kolb, University of Wisconsin-Parkside (United States)

Victor A. Gallardo, Universidad de Concepción (Chile)

3 Instrumentation for Astrobiology

Nilton O. Renno, University of Michigan (United States)

4 Mars, Venus, and Astrobiology I

Donald Platt, Micro Aerospace Solutions, Inc. (United States)

Michael C. Storrie-Lombardi, Kinohi Institute (United States)

5 Mars, Venus, and Astrobiology II

David S. McKay, NASA Johnson Space Center (United States)

Charles V. Rice, University of Oklahoma (United States)

6 Microbial Extremophiles I

Prasanta K. Mukhopadhyay, Global Geoenergy Research Ltd. (Canada)

W. Brigham Klyce, Astrobiology Research Trust (United States)

7 Microbial Extremophiles II

Gregory A. Konesky, K-Plasma Ltd. (United States)

8 Astrobiology and Planetary Protection

Richard B. Hoover, NASA Marshall Space Flight Center (United States) and National Space Science and Technology Center (United States) 


\section{Part 2 X-Ray, UV, Visible, and IR Instrumentation for Planetary Missions}

Conference Chair

Kurt D. Retherford, Southwest Research Institute (United States)

Program Committee

Michael W. Davis, Southwest Research Institute (United States)

Thomas K. Greathouse, Southwest Research Institute (United States)

Session Chair

1 X-Ray, UV, Visible, and IR Instrumentation for Planetary Missions

Kurt D. Retherford, Southwest Research Institute (United States) 
Downloaded From: https://www.spiedigitallibrary.org/conference-proceedings-of-spie on 26 Apr 2023

Terms of Use: https://www.spiedigitallibrary.org/terms-of-use 


\section{Introduction to Part 1: Instruments, Methods, and Missions for Astrobiology XII}

The Instruments and Methods for Astrobiology and Planetary Missions XII conference was extraordinary in its breadth and scope, and features papers representing major developments in the multidisciplinary study of the origin, evolution, and distribution of life in the universe. Many of the papers suggest that life may be a cosmic imperative rather than restricted to the planet Earth. The NASA Astrobiology Program was initiated in 1996 just after the announcement of the detection of biomarkers and possible microfossils in the Mars Meteorite ALH84001. This volume begins with a review of the current status of the evidence for biomarkers and microfossils in ALH84001, and compares new images of biomorphs in two other Mars meteorites (Nakhla and Yamato 000593) with known microfossils from the Columbia River Basalts. The next paper presents evidence for large filamentous microfossils embedded in freshly fractured interior surfaces of the Murchison and Orgueil carbonaceous meteorites. Several of these filaments exhibit unambiguously biological specialized cellular structures such as basal, terminal or intercalary heterocysts. Heterocysts are used for nitrogen fixation and are seen in the trichomic heterocystous cyanobacteria. These filaments in carbonaceous meteorites are of the proper size and exhibit detailed morphological characteristics observed in modern heterocystous cyanobacteria from environmental samples or grown in culture. Energy Dispersive X-ray Spectroscopy (EDX) data indicate that the nitrogen content of the meteorite filaments is generally below the detection limit. This is also observed in fossil trilobites and Proterozoic cyanobacteria fossils, even though nitrogen is easily detectable ( 2-18\% atomic) in modern biological filaments since nitrogen is present in the amino acids, DNA and proteins of all known living organisms. The missing nitrogen provides evidence that the filamentous microstructures in the meteorites are not modern biological contaminants. SEM images and chemical compositions of filamentous microfossils in Paleo-Proterozoic and modern Pillow Lavas establish that bacterial paleontology must not be restricted to the search for microfossils in sedimentary rocks.

Perhaps even more important is the observation that only eight of the twenty protein amino acids common to all life on Earth are found in meteorites. The amino acids that have been found in meteorites were also detected during early studies of lunar soil samples returned to Earth by the Apollo Missions. Nineteen of the twenty protein amino acids have asymmetric centers and are exclusively of the L- enantiomer in living organisms. Amino acids produced by abiotic mechanisms, and in very ancient sediments, are generally racemic, with equal numbers of the D- and L- forms. Although abiotic processes for producing nonracemic amino acids under natural conditions have recently been developed, the indigenous extraterrestrial amino acids found in the meteorites have a much 
greater excess of the L- enantiomer than has been demonstrated by abiotic mechanisms. The partial racemization of amino acids in meteorites may have profound implications to their possible modes of origin as well as for the early chemical evolution and origin of life in the Solar System. Another paper shows that the analyses of complex petroleum-like hydrocarbons present in carbonaceous meteorites are consistent with the breakdown of biopolymers and their transformation to geopolymers and bitumens. These observations coupled with recent discovery of hydrocarbons in Saturn's moons Titan and Hyperion suggests life and petroleum-like hydrocarbons may be more widely distributed in the Solar System than previously thought possible.

Instruments for the remote detection of life are of great importance to astrobiology. Homochirality of biological molecules is a signature of life as we know it. A sensitive new device for determination of chirality in living matter only, was described as a potential new life detection instrument. Similarly, a photoelastic modulator (PEM) based Spectroscopic Polarimeter that has been developed to remotely detect chiral signatures in Astrobiological samples was described. Measurements of the circular polarization spectra of cyanobacteria and minerals are provided. A novel instrument using Laser Induced Fluorescence Emission imaging and spectroscopy for the remote detection of visible and nearIR fluorescence from biological pigments is described. The results of measurements obtained with this instrument during field studies of cyanobacteria-dominated microbial communities within the of ice-covered lakes in Antarctica and Alaska are presented. The target photosynthetic microorganisms live and thrive in the ice itself. The only liquid water is a thin layer at the boundary between millimeter scale cryoconite dust and the surrounding ice. The assemblages should be easily observed during in-situ, airborne, and orbital exploration of icy cryospheres independent of the existence of freestanding sources of liquid water. This exciting new technology may find important applications for autonomous systems designed to remotely search for life in the icy polar regions of Mars or in the cryospheres of icy moons or exoplanets. Recognition of spectral bio-signatures in exoplanets requires an understanding of the spectral biosignature of planet Earth. An Integrated Ray Trace Model has been developed and used to compute the Disk Averaged Spectra of the full 3-D Earth model to assess its applicability for sensing water, surface vegetation, and biological pigments such as chlorophyll. A novel micro-fluorescent cell sorter instrument that might be applied to distinguish and sort live bacterial cells from dead bacteria and mineral grains in ice and permafrost is also described.

Ever since the 1976 Viking Missions to Mars, NASA has adopted the theme "Follow the Water" as a guide to where life may be found. It has been the paradigm that the water must be in liquid state. The apparent absence of liquid water on Mars has long been one of the main arguments against the possibility of that the Viking Labeled Release (LR) experiment data established the existence of present day life on Mars. The Phoenix Mission recently obtained observational evidence for present day liquid water on Mars. Phoenix images indicate that the Landing Thruster plumes exposed subsurface ice and splashed liquid water brines forming droplets on the struts of the Phoenix Lander. Their time-lapse images and the 
theoretical demonstration that the thermodynamics of freeze-thaw cycles lead to the formation of brines that can be in liquid state almost anywhere that ground ice exists near the surface of Mars. Another paper re-examines the original LR data in view of the recent discovery of methane in the atmosphere of Mars correlated with atmospheric water vapor. This paper suggests that a simple variation introducing chirality to the Viking LR experiment would make it possible to differentiate a chemical response from a biological response of microorganisms that prefer D- sugars and L- amino acids or the alternate chirality isomers. Phoenix also reported perchlorate in the surface regolith of Mars. Microorganisms on Mars might metabolize perchlorate, as do some species on Earth-making it life-sustaining rather than life-threatening. The oxidation resistance of glycine, alanine and heterocycles indicates that they would survive contact with Mars regolith perchlorates, making it unlikely that perchlorate oxidation could account for the failure of the Viking or Phoenix missions to detect these widely expected organics in the Mars regolith. The discovery of perchlorate on Mars led to a study of the fractal dimensions of the perchlorate reductase gene sequences of Dechloromonas and the suggestion that time resolved UV fluorescence studies of nucleotide emission bands could lead to a novel Astrobiology instrument to search for evidence of life on Mars, especially in ancient lake beds. The next paper discusses the possibility that acidophilic hyperthermophiles might find possible habitable zones in the liquid droplets in the upper layers of the clouds of Venus and that they might be responsible for cloud absorption features observed in the UV. An instrument id described that could be deployed on a Mars Rover. Raman imaging is used to search for molecular biomarkers ( $\mathrm{C}-\mathrm{C}, \mathrm{C}-\mathrm{O}$, and $\mathrm{C}-\mathrm{N}$ ) and pigment molecular signatures as evidence of biological activity and life on Mars. The feasibility of this technology is shown in laboratory studies of Mojave Desert quartz colonized by cyanobacteria and by the detection of peaks associated with the beta-carotene pigments of red snow algae from Lassen Volcanic National Park.

Several papers are concerned with microbial extremophiles. Novel aerobic and anaerobic microorganisms were studied in situ and isolated from samples collected during the 2008 Expeditions to the Schirmacher Oasis and Lake Untersee of Antarctica. Culture dependent and culture independent methods revealed the existence of a dynamic microbial ecosystem in the Schirmacher Oasis lakes. The microbial biodiversity of the oasis lakes is much greater than previously reported and it is probably driven by a unique combination of glacialological, climatological, geological, and biological factors. The cell morphologies and growth characteristics are described for interesting new strains of anaerobic psychrophilic and psychrotolerant microorganisms that were isolated from ice and water samples collected from Lake Untersee, Lake Zub, and Lake Podprudnoye. Two novel strains of psychrophilic homoacetogens were discovered in inoculates from the deep anoxic trough of Lake Untersee. These psychrophilic homoacetogens are motile vibrions that may be of great significance to Astrobiology. These homoacetogens are able to grow at $5^{\circ} \mathrm{C}$ with hydrogen and carbon dioxide serving as their sole source of energy and carbon 
and may represent analogs for life that could survive on the Polar Caps of Mars or the Icy Moons of the Solar System.

Interesting new discoveries about Life in Ice may result in a need to understand the "Follow the Water" mantra of Astrobiology from a new perspective. Studies of microbes in the permafrost, cryoconites and ice bubble ecosystems of the polar regions of Earth have shown that many bacteria exhibit motility as soon as the ice or frozen soil that entraps them is thawed. Cryopreserved prokaryotic and eukaryotic microorganisms have been found in the ancient ice and permafrost from Alaska, Siberia, and deep ice cores from Greenland and Vostok, Antarctica. Many of these are viable, can be grown in pure culture and have been validly published as new genera or species previously unknown to science. Many microbes are preserved as spores or dormant organisms in a state of deep anabiosis. However, every sample of ice studied during recent expeditions to Alaska and Antarctica contained microorganisms that were alive and exhibited locomotion as soon as the ice was melted on sterile slides under the darkfield video microscopy system. This astonishing observation may be explained by recent studies that have found that many polar diatoms, fungi, snow molds, algae, cyanobacteria and bacteria secrete antifreeze proteins or ice binding proteins. These natural antifreeze substances appear to trigger pitting or localized melting of ice crystals, thereby providing adequate quantities of liquid water for microbial metabolism, and consequently making life in ice possible. Laboratory NMR and fluorescence spectroscopy studies have revealed that teichoic acid cell-wall peptidoglycan protects liquid water at temperatures far below $0^{\circ} \mathrm{C}$. This important new property of teichoic acid was deduced from $31 \mathrm{P}$ and $2 \mathrm{H}$ solidstate NMR data for teichoic acid dissolved in $\mathrm{D}_{2} \mathrm{O}$. This study revealed that the teichoic acid, which comprises $\sim 50 \%$ of the mass of the cell walls of Gram positive bacteria, is surrounded by liquid water at temperatures as low as $-40^{\circ} \mathrm{C}$. The NMR results indicate that the liquid water forms pockets or channels around the bacteria. This property would permit the exchange of liquid water, nutrients, salts and waste products across the bacterial cell wall and provide a liquid regime within the ice in which microbial metabolism and motility could occur. These discoveries indicate that water ice must be considered a significant component of the "Follow the Water" paradigm of Astrobiology. Hence the Polar Ice Caps of Mars and the near surface crustal layers of comets and the icy moons of Jupiter and Saturn should be considered prime Astrobiology targets in the search for Life in the Solar System. Furthermore, the phenomena of life in ice may have important implications to the possibility of transfer of viable microorganisms from one solar system body to another by cryopreservation in the ices of comets or impact ejection of water ice from the cryospheres of planets or moons of our Solar System. This could be relevant to the origin of life on Earth and the distribution of life throughout the cosmos.

The Single Stranded DNA Binding Protein (RPA) genes in a gamma-ray radiationresistant halophilic archaeon (Halobacterium sp. NRC1) were analyzed in terms of their nucleotide fluctuations to correlate randomness by Fractal Dimension Analysis. This study indicated that the Halobacterium sp. NRCl sequence is not random and the nucleotide fluctuations and that the fractal dimensions, 
Shannon Entropies $y$, and the CPG dinucleotide pair percentages were comparable to those of the radiation repair gene of Deinococcus radiodurans. Halophilic archaea with similar radiation resistance genes could have existed on ancient Mars and may yet be present beneath salt-rich evaporites in craters and basins of present day Mars. A spectrofluorimetric study of the autofluorescence properties of the puzzling culturable bodies found in incidents of red-rain (last reported in July, 2008 in Kerala, India) and in the particulates found in the yellow rain (as recently as 31 July, 2008 in Columbia) indicated that these widely separated phenomena are connected. It is theorized that they may have arrived with the infall of meteoritic material.

It was proposed that horizontal gene transfer, while not immediately seen as such but ultimately consistent with Darwinian theory, is responsible for the appearance of new species. Whole genes are transferred from one organism to another; imparting the properties that constitute a new species. Sequences of genes have not yielded evidence of gradual evolution, there being no intermediate species. It was theorized that our immunity derives from a transposon some 400 million years ago. The implications of horizontal gene transfer to the possibility of panspermia are considered.

The relevance to astrobiology of the philosophical problems of identify, as it relates to the definition of life, was explored. The pedagogical connection of green chemistry to astrobiology was also discussed.

In summary, many discoveries obtained during the last 50 years suggest that the Drake Equation needs to be re-visited. Expeditions to some of the most hostile environments on Earth have shown that life seems to exist on Earth virtually everywhere that water (or water ice) co-exists with a source of energy and a suite of life-critical biogenic elements. Sensitive astronomical methodologies have revealed the existence of a host of extra solar planets. This new information has greatly expanded our understanding of the conditions and parameters in which life exists. It provides valuable data to help guide us in the development of new instruments, spacecraft, and missions to search for extra-solar planets that could support life as we know it, and to find and recognize evidence of life that may be found in ancient terrestrial rocks and meteorites or may be producing biosignatures as it inhabits other bodies of the cosmos.

\author{
Richard B. Hoover \\ Gilbert V. Levin \\ Alexei Yu. Rozanov
}


Downloaded From: https://www.spiedigitallibrary.org/conference-proceedings-of-spie on 26 Apr 2023

Terms of Use: https://www.spiedigitallibrary.org/terms-of-use 